\title{
THE EFFECT OF ANIMAL PROTECTION ADVERTISING ON OPPOSITION TO THE SLAUGHTER OF WILDLIFE AND WILLINGNESS TO BOYCOTT THE OFFENDING INDUSTRY: INITIAL AND CARRYOVER EFFECTS
}

\author{
Karin Braunsberger, University of South Florida St. Petersburg, USA
}

\begin{abstract}
During the last decade, concerns for both the welfare and rights of animals have moved into the mainstream (Severson 2007; Siebert 2010; Singer 2006). Accordingly, it comes as no surprise that we have observed an increase in the number of individuals who disapprove of all sport fishing, hunting, and trapping activities (Arlinghaus et al. 2012). The Canadian and Namibian seal hunts, for example, have been drawing growing criticism for years (Smith 2011; UPI 2012), as have the Japanese whale and dolphin hunts (McCurry 2009; Morell 2008).

Even though research has shown that media coverage can affect public perceptions and therefore the choices consumers make (Kalaitzandonakes, Marks and Vickner 2004), empirical examination of the effect of media coverage on consumer choices as they relate to animal welfare and animal rights has - to date - mainly focused on concerns relating to farm animals (Tonsor and Olynk 2011). Hardly any empirical research to date has examined whether advertising focusing on animal cruelty, animal welfare, and animal rights issues has a comparable effect (for a notable exception, see Richards, Allender and Fang 2011). Thus, the purpose of the current study is five-fold. First, it examines not the effect of media attention but rather the effect of advertising on consumer choices and behaviors. Second, in addition to testing the impact of the ad itself, the study examines the actions taken by viewers to learn more about the issue. A third purpose of the present study is to add another focus to animal welfare issues, specifically as they relate to wildlife rather than farm animals. Fourth, the current research examines whether consumers are willing to boycott the industry that is involved in the cruel acts shown in the ad. And fifth, it measures and compares the initial and carryover effects of the advertisement. Consequently, the present study is the first to date to measure the effectiveness as well as carryover effects of an animal protection advertisement on consumer opposition to perceived animal cruelty and willingness to boycott the offending party.

The video ad used in the current study had been developed by Harpseals.org with the goal to raise awareness about the Canadian seal hunt, and to increase opposition to the seal hunt as well as participation in the Canadian Seafood Boycott (see http://www.harpseals.org/resources/toolbox/video_audio/harpseals_flash_video.php). The ad shows scenes of the seal hunt, including material that shows a sealer about to club a harp seal pup with a hakapik (a club with a hook at its tip), and the bodies of dead seals scattered across the ice. The goal of the boycott is to permanently end the annual Canadian Seal Hunt. The data for Waves 1 and 2 were collected online via a web panel provided by Global Market Insite, Inc. (GMI). After the initial opposition to the egregious acts was measured, respondents viewed the ad, and then asked again about their opposition to the egregious act as well as their willingness to boycott the offending industry. Approximately two months later, a followup study examined whether the respondents' opposition to the egregious act and their participation in the boycott against the offending industry were still impacted by the advertisement they had watched during the first wave of data collection.
\end{abstract}

The findings show that the level of opposition to the egregious acts-although it had leveled off in two months-was still significantly higher (42\%) than before respondents had seen the advertisement. The findings further illustrate that the single exposure to the ad boosted boycott participation by $479 \%$.

References available upon request 